\title{
Broiler Transportation Conditions in a Brazilian Commercial Line and the Occurrence of Breast PSE (Pale, Soft, Exudative) Meat and DFD-like (Dark, Firm, Dry) Meat
}

\author{
Roselane Oliveira de Souza Langer ${ }^{1}$, Gislaine Silveira Simões ${ }^{1}$, Adriana Lourenço Soares ${ }^{1}$, \\ Alexandre $\mathrm{Oba}^{2}$, Alessandro Rossa ${ }^{3}$, Massami Shimokomaki and Elza Iouko Ida ${ }^{1^{*}}$ \\ ${ }^{1}$ Departamento de Ciência e Tecnologia de Alimentos; Universidade Estadual de Londrina; C. P.: 6001; 86051- \\ 970; Londrina - PR - Brasil. ${ }^{2}$ Departamento de Ciência Animal; Centro de Ciências Agrárias; Universidade \\ Estadual de Londrina; C. P.: 6001;86051-970; Londrina - PR - Brasil. ${ }^{3}$ Universidade Estadual de Londrina; Rua \\ Claudio Zatta, 35; Cafelândia - PR - Brasil
}

\begin{abstract}
The objective of this work was to investigate the effect of road transportation conditions on the occurrence of broiler PSE- (Pale, Soft, Exudative) and DFD-like (Dark, Firm, Dry) meats in the Brazilian commercial slaughterhouse plant. Samples of Pectoralis major $m$ from 47-day-old broilers of commercial lineage were analyzed. The results indicated that water-bathing birds just before journey over $3.0 \mathrm{~km}$ promoted the occurrence of $46.0 \%$ of PSE and $4.0 \%$ of DFD-like meat, while birds under non-water bathing conditions presented 14.7 and 2.0\%, respectively. For a distance of $68.0 \mathrm{~km}$, the occurrences of PSE- and DFD-like meat were 44.0 and $0.0 \%$ under water bathing conditions, and 52.0 and $0.0 \%$ without water bathing, respectively. Water bathing at the farm was a critical manoeuvre for increasing the unfavourable truck microenvironment for short journey, whereas conversely for longer journey it was less stressful influencing the broiler breast meat quality.
\end{abstract}

Key words: truck microclimate, meat quality, broiler chicken stress

\section{INTRODUCTION}

Stress is a common term for a set of bodily reactions to situational aggression physical, psychological, or other, capable of disturbing the body homeostasis (Olivo and Shimokomaki, 2006). Under these circumstances and at a relatively high temperature, bird respiratory frequency tends to rise and muscle arteries and veins dilate to dissipate residual body heat (Furlan et al., 2005). These factors may affect its final meat qualities (Mitchell and Kettewell 1998).
Transportation is a relevant factor in the control of harmful conditions that also influence meat quality. Birds are subject to various potential stressors in trucks, such as heat, acceleration, vibration, movement, impact, food and water deprivation, social disruption, and noise. Thermal stress is one of the most important factors, and there is strong evidence that the longer the journey, the higher the death rate (Mitchell and Kettewell 1998. Warriss et al. (2005) reported $0.126 \%$ broiler dead on arrival (DOA) in the UK under transportation below $17^{\circ} \mathrm{C}$ while at 20.0 -

*Author for correspondence: elida@uel.br 
$22.9^{\circ} \mathrm{C}$, DOA was 6.6-fold higher. Therefore, the best condition for keeping the birds welfare is the relative lower temperature value. Unfortunately, no report is currently available on this subject in Brazilian conditions. Overall, the common transportation practice for broiler management in this country follows the sequence: 1) food and water deprivation, 2) catching, crating, and watering the birds in the truck before transportation, 3) transportation, and 4) water nebulization and lairage upon arrival at the processing plant. This work aims to quantify the occurrence of PSE (Pale, Soft, Exudative) and DFD-like (Dark, Firm, and Dry) broiler meat occurrence under transportation conditions from farm to commercial processing plants such as distance, watering the birds in the truck before journey and truck microclimate during journey.

\section{MATERIALS AND METHODS}

\section{Two experiments were designed}

Experiment $I$ in the summer season: Effect of watering and journey distance on the occurrence of PSE and DFD-like meat.

\section{Birds and Treatments}

This experiment was carried out in the southern region in the summer of 2006 to observe the effect of transportation conditions from the farm to the broiler chicken processing plant following the flow chart illustrated in Figure 1. Six hundred 47day old broilers were divided into two lots: a control lot $(C L)(n=300)$, in which the birds were not water bathed after vehicle loading and before journey and a treated lot $(\mathrm{TL})(\mathrm{n}=300)$ in which birds were bathed at room temperature around $30^{\circ} \mathrm{C}$ for about $7 \mathrm{~min}$ after loading into a truck before journey. The birds were firstly transported to a commercial processing plant at a relatively short distance of $3.0 \mathrm{~km}$ from the farm and secondly of $68.0 \mathrm{~km}$ away. Both lots were sprinkled with water upon arrival and followed by ventilation during lairage for about $50 \mathrm{~min}$ to keep the birds calm (Guarnieri et al., 2004). The broilers were slaughtered, breast fillets (Pectoralis major $m$.) were collected, and $\mathrm{pH}$ and color were evaluated after 24-h post-mortem and stored at $2 \pm$ $2^{\circ} \mathrm{C}$.

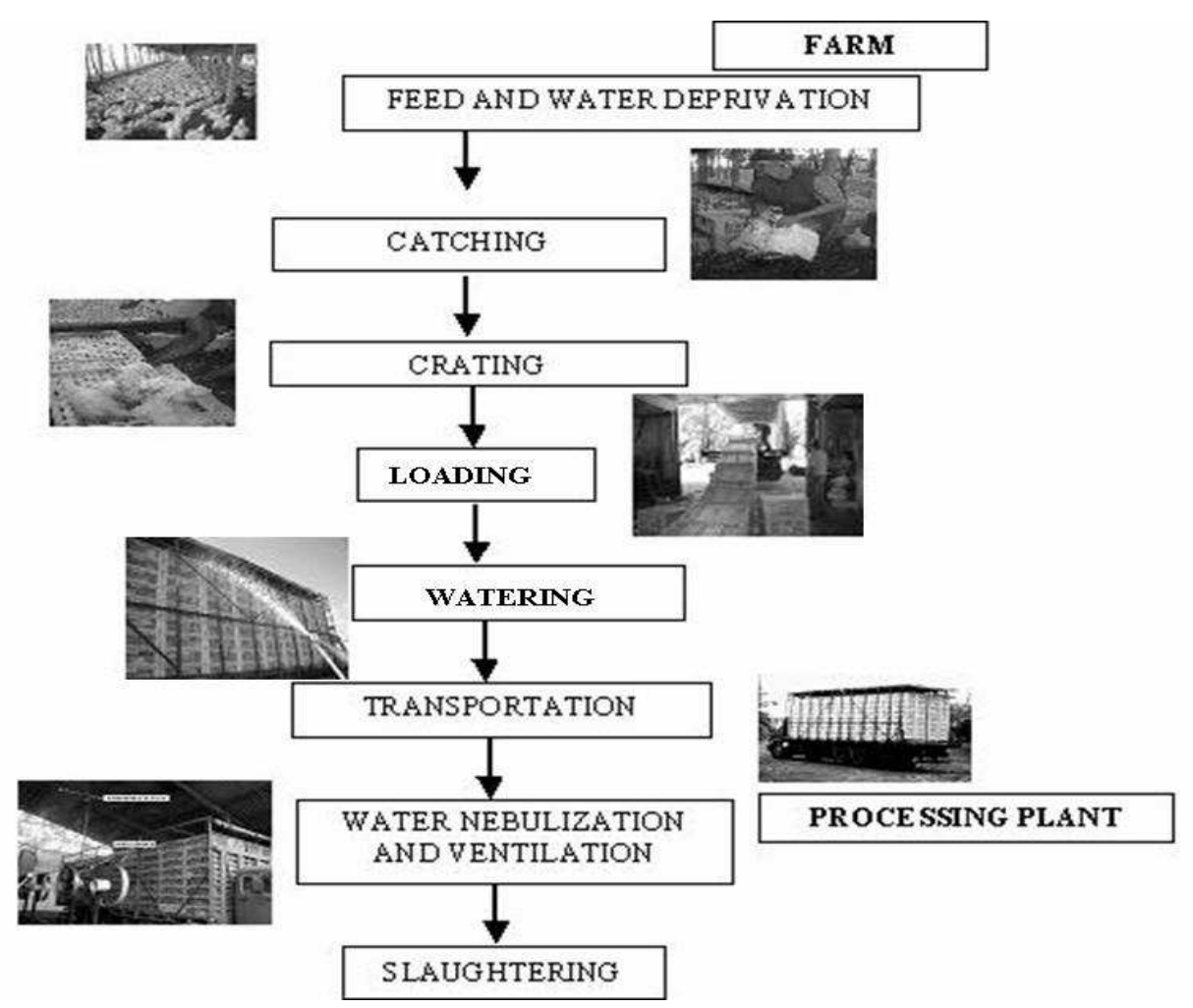

Figure 1 - Broiler handling sequence for transportation from farm to processing plant 


\section{pH Measurement}

$\mathrm{pH}$ was measured by inserting electrodes into the breast muscle using a $\mathrm{pH}$ meter (Sentron 1001 pHmeter). Analyses were performed in triplicate on refrigerated samples $24 \mathrm{~h}$ post-mortem as reported in Olivo et al. (2001).

\section{Colour Measurement}

A Minolta CR400 colorimeter was used to evaluate the colour, $\mathrm{L}^{*}\left(\right.$ lightness), $\mathrm{a}^{*}$ and $\mathrm{b}^{*}$ (CIELAB colour system) on the posterior surface of intact skinless breast muscles at $24 \mathrm{~h}$ post-mortem. The color values were measured at three different sites of the same sample (Olivo et al. (2001).

\section{Sample Classification}

Meat samples were classified as PSE, DFD-like, or normal based on previously established parameters associated with $\mathrm{pH}, \mathrm{L}^{*} \geq 53.0$ as PSE, $\mathrm{L}^{*} \leq 44.0$ as DFD-like, and $44.0<\mathrm{L}^{*}<53.0$ as normal (Soares et al. 2002).

\section{Statistical Analysis}

Statistical analyses were performed using the program Statistica 7.0 for Windows. The Student t test (5\%) was applied to compare the mean values between two treatments: CL and TL.

\section{Experiment II in the winter season}

Effect of truck microenvironment on the occurrence of PSE- and DFD-like meat.

\section{Materials}

This experiment was carried out in the southern region in the winter of 2008. Broilers $(n=270)$ of 43-days old of commercial lineage were transported from farm to commercial plant during $85 \mathrm{~min}$ journey. Upon arrival at the processing plant, the trucks were driven to holding places where the birds were left at rest while they were submitted to a water mist and ventilation before slaughtering. After slaughtering, breast fillets (Pectoralis major m.) were collected, and $\mathrm{pH}$ and color were evaluated after $24 \mathrm{~h}$ post-mortem storage at $2 \pm 2^{\circ} \mathrm{C} . \mathrm{pH}$ and color were measured and samples were classified as PSE and DFD-like meat as described in Soares et al. (2002).

\section{Measurement of in-vehicle temperature and relative humidity $(\mathrm{RH})$}

Thermologs consisting of a thermometer and a RH meter were placed at six different locations in the truck: two apparatus at the front, two in middle, and two at the rear, as shown in Fig 2. The space between crates was about $20-30 \mathrm{~cm}$, and the total load was around 3,000 birds per truck.
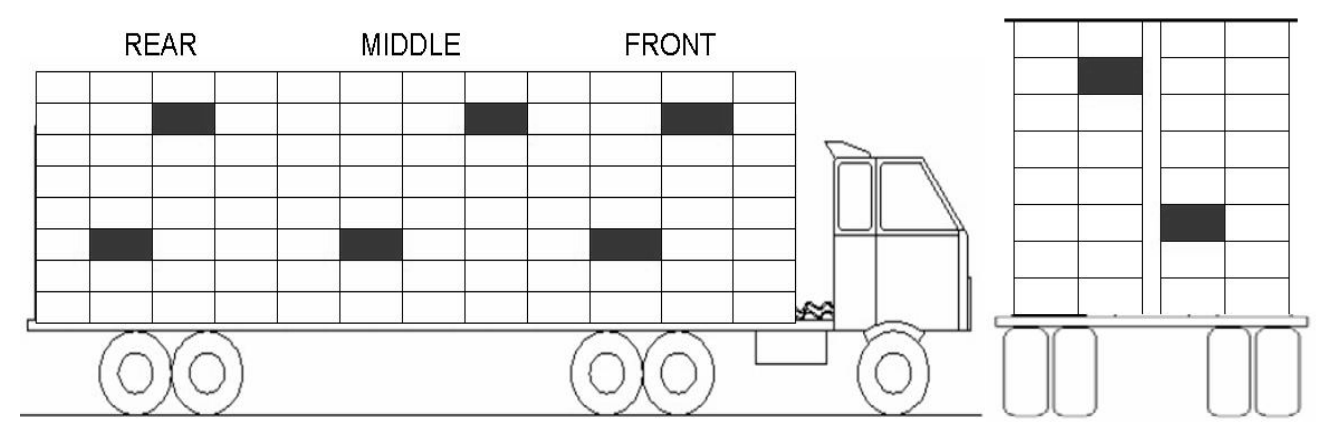

Figure 2 - a) Location of thermologs in the lorry loaded with broilers and b) rear view of the truck. Adapted from Barbosa-Filho (2008). 


\section{RESULTS AND DISCUSSION}

\section{Experiment $I$ in the summer season}

Effect of watering and distance journey on the occurrence of PSE- and DFD-like meat. Tables 1 and 2 present the meat $\mathrm{pH}$ and color results for CL and TL samples transported 3.0 and $68.0 \mathrm{~km}$, respectively. Table 1 showed that the CL samples presented higher $\mathrm{pH}$ and lower $\mathrm{L}^{*}$ values $(\mathrm{P}<0.05), \mathrm{a}^{*}$ values were significantly higher, and $\mathrm{b}^{*}$ values were lower for the CL samples compared to TL samples. These results indicated that TL samples contained a larger amount of paler meat with relatively low $\mathrm{pH}$ values typical of broiler PSE meat (Olivo et al., 2001). The incidence of PSE and DFD-like meat in CL and TL samples transported for $3.0 \mathrm{~km}$ are shown in Figure 3. CL samples contained 14.7\% PSE and $2.0 \%$ DFD-like meat, whereas TL samples contained $46.0 \%$ PSE and 4.0\% DFD-like meat. As observed in Table 2, the measured $\mathrm{pH}$ and colour values of the CL and TL samples from birds transported $68.0 \mathrm{~km}$ did not differ significantly. The distribution of the amount of PSE meat in both treatments is shown in Fig 4. The CL exhibited 52.0\% PSE meat, TL exhibited $44.0 \%$ PSE meat, while DFD-like meat was not detected in both lots for this distance journey.

These results clearly showed the beneficial effect of birds watering in the truck while at the farm, indicating that the microenvironment improvement provided by ventilation during long distance journey could help the birds to reach the $\mathrm{Ca}^{2+}$ muscle homeostasis controlled by ryanodine proteins, which played distinct roles in muscle excitation-contraction coupling, as recently reported (Oda et al., 2009). A reasonable explanation for the results obtained herein involved the bird water bathing within the vehicle before the journey step (Fig.1) and the consequent increase in the truck microenvironment temperature, which contributed to the induction of stress, particularly thermal stress. PSE meat formation was higher for $3.0 \mathrm{~km}$ with in-truck bathing than without it. Most probably, the shortdistance conditions did not allow enough time for refreshing the animals by the journey ventilation. Conversely, for the $68.0 \mathrm{~km}$ journey, the microenvironment conditions were significantly improved, as demonstrated by the decrease in the amount of PSE in the TL, an indication that the broilers reached $\mathrm{Ca}^{2+}$ muscle equilibrium more rapidly.

Under hot temperature of Brazilian tropical journey conditions could result in the bird hyperthermia, thus causing the PSE abnormality development (Soares et al. 2002, Olivo and Shimokomaki, 2006). There are fundamental differences between the UK and Brazil birds management conditions, the most obvious are the differences in the climates, which are temperate and tropical, respectively. Also, while in Britain, the birds are routinely transported in containers in Brazil, trucks are open. As such, during the summer, the birds are water bathed while at the farm, a factor that must be critically evaluated.

Table $1-\mathrm{pH}, \mathrm{L}^{*}, \mathrm{a}^{*}$, and $\mathrm{b}^{*}$ values of broiler breast fillet from control lot (CL) and treated lot (TL) samples taken from birds transported for $3.0 \mathrm{~km}$ journey.

\begin{tabular}{ccccc}
\hline Lot & $\mathbf{p H}$ & $\mathbf{L}^{*}$ & $\mathbf{a}^{*}$ & $\mathbf{b}^{*}$ \\
\hline $\mathrm{CL}$ & $6.46^{\mathrm{a}} \pm 0.18$ & $49.89^{\mathrm{b}} \pm 3.01$ & $1.85^{\mathrm{a}} \pm 0.95$ & $9.97^{\mathrm{b}} \pm 1.52$ \\
$\mathrm{TL}$ & $6.14^{\mathrm{b}} \pm 0.12$ & $52.53^{\mathrm{a}} \pm 3.85$ & $1.45^{\mathrm{b}} \pm 0.87$ & $11.43^{\mathrm{a}} \pm 1.52$ \\
\hline
\end{tabular}

Different letters on the same column indicate statistical difference by Student $\mathrm{t}$ test $(\mathrm{p}<0.05)$.

Table $2-\mathrm{pH}, \mathrm{L}^{*}, \mathrm{a}^{*}$, and $\mathrm{b}^{*}$ values of broiler breast fillet meat (Pectoralis major m.) from control lot (CL) and treated lot (TL) samples taken from birds transported for $68.0 \mathrm{~km}$ journey.

\begin{tabular}{ccccc}
\hline Lot & $\mathbf{p H}$ & $\mathbf{L}^{*}$ & $\mathbf{a}^{*}$ & $\mathbf{b}^{*}$ \\
\hline $\mathrm{CL}$ & $6.05 \pm 0.09$ & $52.89 \pm 2.57$ & $2.10 \pm 0.78$ & $12.51 \pm 1.66$ \\
$\mathrm{TL}$ & $6.07 \pm 0.10$ & $52.67 \pm 2.90$ & $2.10 \pm 0.88$ & $12.34 \pm 1.92$ \\
\hline
\end{tabular}



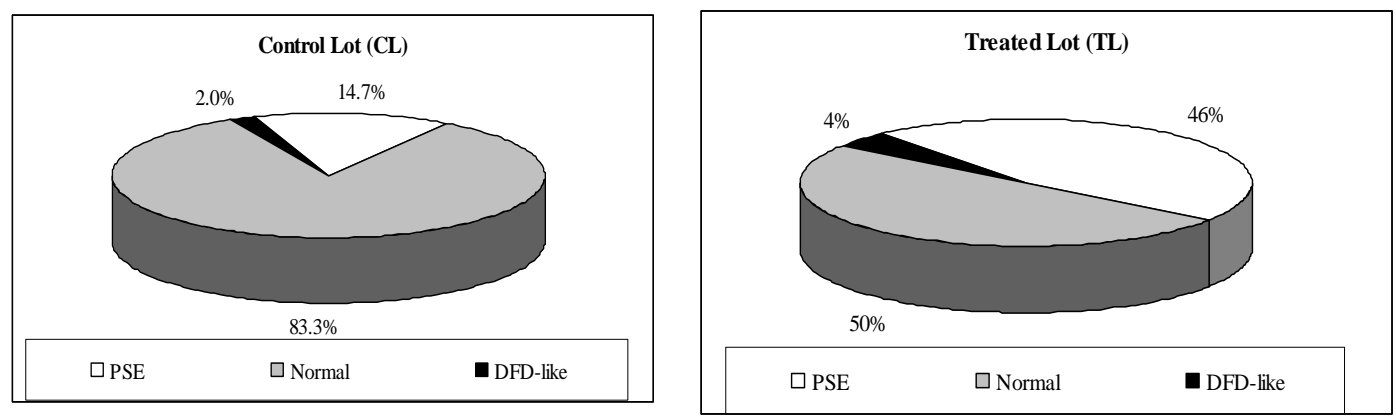

Figure 3 - Occurrence of PSE and DFD-like broiler breast meat in control lot (CL) and treated Lot (TL) samples taken from birds transported for $3.0 \mathrm{~km}$ journey.
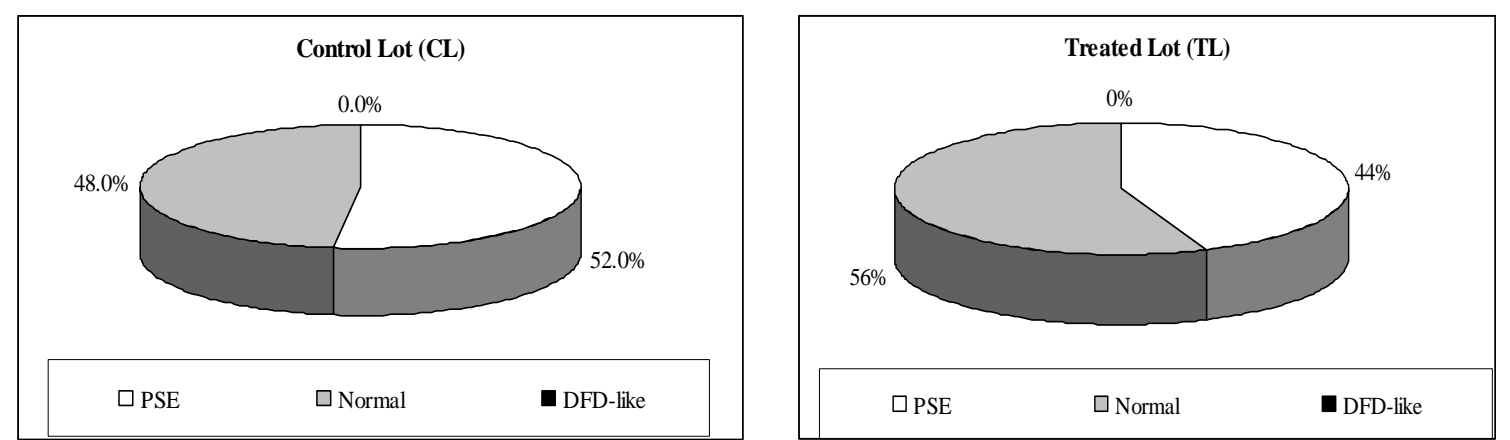

Figure 4 - Broiler breast fillet PSE and DFD-like meat in control lot (CL) and treated Lot (TL) samples taken from birds transported $68.0 \mathrm{~km}$.

\section{Experiment II in the winter season}

Effect of truck microenvironment on the occurrence of PSE and DFD-like meat

Figure 5 shows typical temperature variations at three different locations (front, middle, rear) within the truck during the 85-min road journey to the commercial plant with immediate nebulization and ventilation application. The environmental temperature was between 15 and $17^{\circ} \mathrm{C}$, and the temperature within the vehicle was between 25 and $33^{\circ} \mathrm{C}$ for an $85-\mathrm{min}$ road journey up to 130 min after arrival at the commercial pilot plant (Fig. $5)$. The highest temperature was recorded at the rear of the vehicle. This experiment showed that truck in-ventilation was heterogeneous during the journey. A strong wind blown at the front of the vehicle, and decreased gradually towards the middle and the rear of the vehicle (Fig. 6). The temperatures were similar after nebulization treatment at the commercial plant (Fig 5) suggesting that partial broilers physiological homoeostasis could be reached. Although the birds were calmed, the water treatment was not enough to alleviate the stress suffered by the animals. PSE meat evaluation in poultry breast meat samples using $\mathrm{pH}$ and color measurements resulted in the observation of a higher percentage of PSE meat in birds placed at the truck rear followed by those in the middle and finally at the front of the vehicle, as illustrated in Fig 7. Since no DFD-like sample was detected in birds placed at the rear and it was observed in samples from the front and in lesser amounts in samples from the middle region, it appeared that the birds located at the front of the vehicle were under stronger ventilation and suffered from chilling. In order to keep warm, they spent more glycogen, thus, the resulting final $\mathrm{pH}$ was higher, which produced DFD-like meat. 


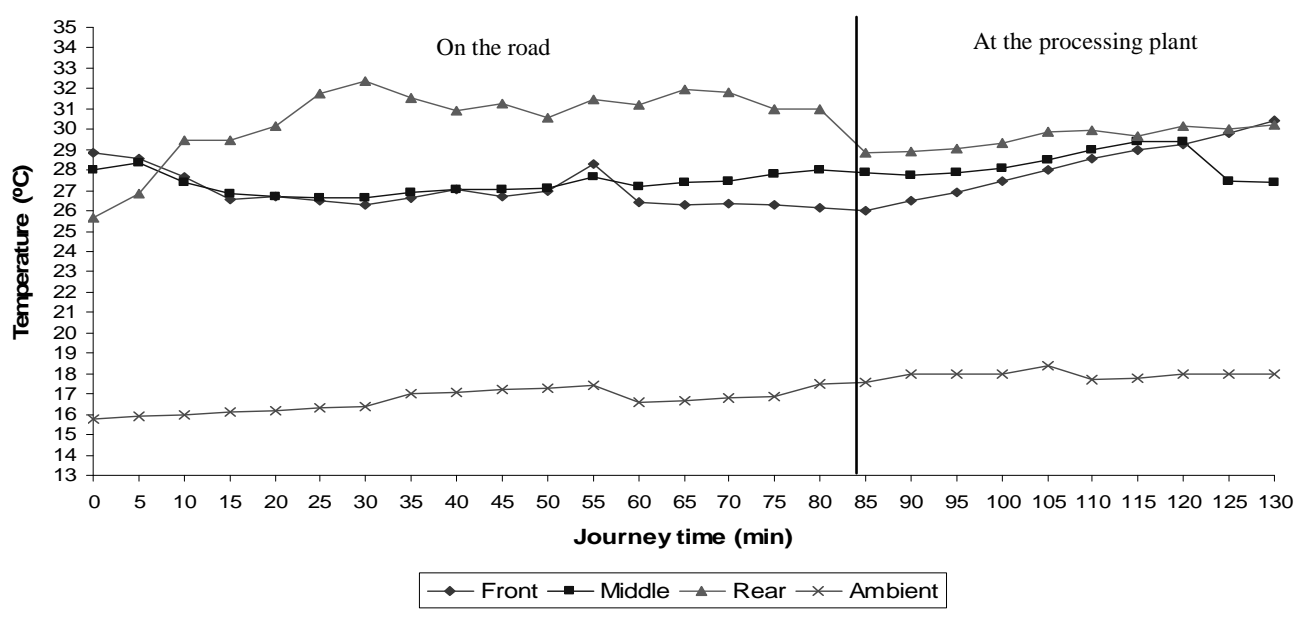

Figure 5 - Temperature distribution measured at three locations within the truck during an 85-min road journey from the chicken farm to the commercial pilot plant. As routinely occurs, nebulization took place soon after arrival at the pilot plant. This experiment was conducted early in the winter of 2008. The ambient temperature was also recorded.

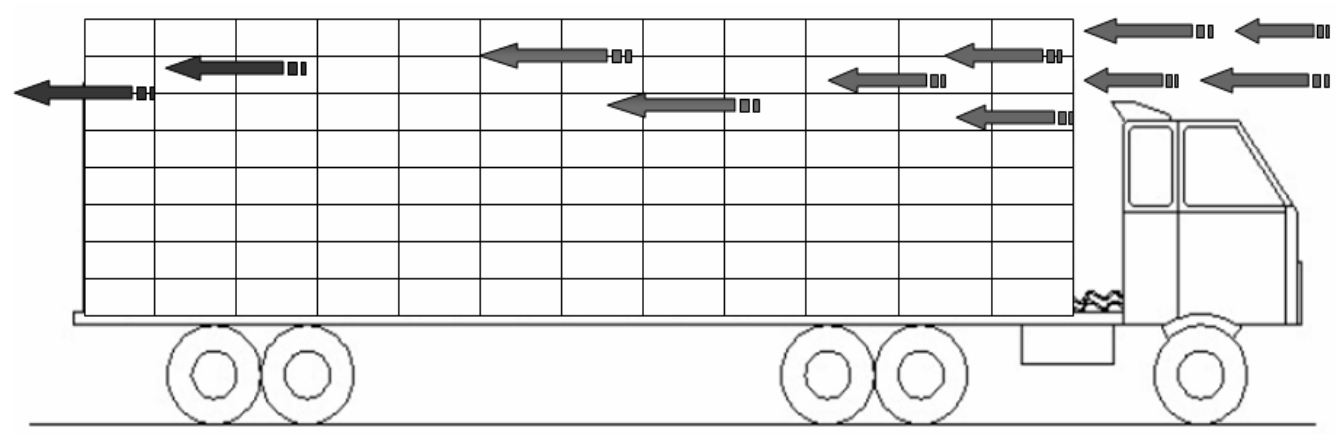

Figure 6 - Typical ventilation distribution in the broiler chicken transportation truck during road journey in Brazilian southern winter conditions. Note that the ventilation was stronger at the front of the truck and gradually decreased towards the middle and the rear of the truck. Adapted from Barbosa Filho (2008).

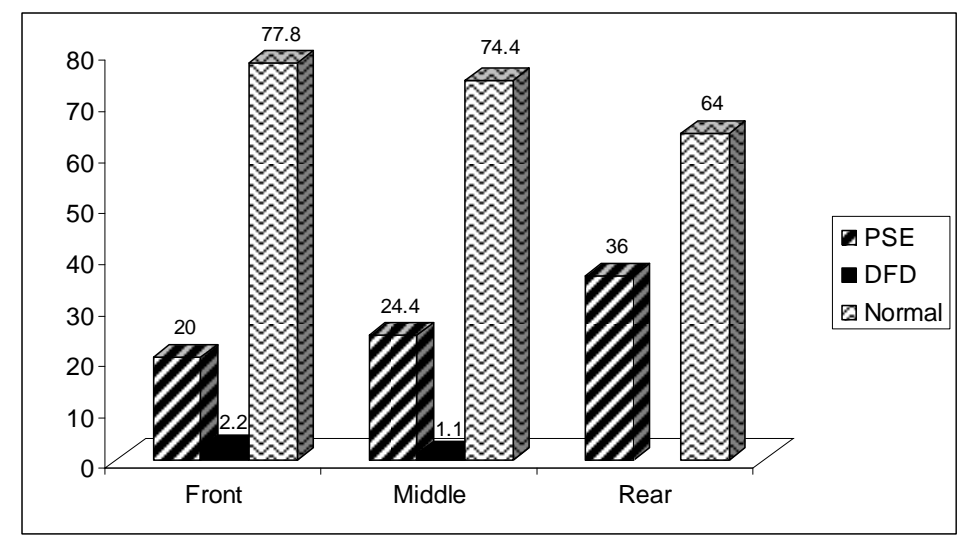

Figure 7 - Occurrence of broiler breast fillet PSE, DFD-like and normal meat. Samples were taken from birds transported in the three vehicle regions, front, middle, rear, after an 85 -min road journey in the early winter of 2008. 


\section{CONCLUSIONS}

Water bathing just before the beginning of the journey from the farm to the slaughterhouse promoted unfavourable conditions for the birds' welfare in short distance transportation; however, for a relatively longer distance, this manoeuvre was beneficial and reduced the amount of PSE meat in the summer season. The temperature variation in the vehicle microenvironment during the road journey led to a temperature rise, proportional to the occurrence of PSE meat.

\section{ACKNOWLEDGEMENTS}

This work was partially funded by $\mathrm{CNPq}$, Fundação Araucária/CNPq Pronex (Protocol \# 09.277). Thanks are also due to CAPES Foundation for a graduate scholarship to GSS. EII and MS are CNPq Research Fellows.

\section{RESUMO}

O objetivo deste trabalho foi investigar o efeito das condições do transporte na ocorrência das carnes PSE (Pale, Soft, Exudative) e a-DFD (Dark, Firm, Dry) de frangos nas condições brasileiras em uma planta de um frigorífico comercial. Foram analisadas amostras de peito de frango (Pectoralis major m.) da ave de 47 dias de linhagem comercial. Os resultados indicaram que o banho dos frangos imediatamente antes da viagem de $3,0 \mathrm{~km}$ promoveu a ocorrência de $46,0 \%$ de PSE e $4,0 \%$ de a-DFD enquanto que frangos sem banho apresentaram 14,7 e 2,0\%, respectivamente. Para uma distância de $68,0 \mathrm{~km}$, a ocorrência de carnes PSE e a-DFD foram 44,0 e $0,0 \%$, respectivamente, de aves que sofreram banho e 52,0 e $0,0 \%$ sem banho, respectivamente. O banho ainda na granja foi uma atividade crítica aumentando as condições desfavoráveis no microambiente do caminhão para curtas distâncias e contrariamente para distâncias longas foi menos estressante influenciando na qualidade do peito do frango.

\section{REFERENCES}

Barbosa-Filho, J. A. D. (2008), Caracterização quantiqualitativa das condições bioclimáticas e produtivas nas operações pré-abate de frangos de corte. PhD Thesis - Escola Superior de Agricultura Luiz de Queiroz - USP, Piracicaba, Brasil.

Furlan, R.L.; Macari, M.; Da Costa, M.J. R.P. (2005), Bem-estar das aves e suas implicações sobre o desenvolvimento e produção. Proceedings of Fórum Internacional de Avicultura, Foz do Iguaçu, Brasil, p.60-68.

Guarnieri, P.D., Soares, A. L., Olivo, R., Schneider, J. P.; Macedo, R. M., Ida, E. I., Shimokomaki, M. (2004), Preslaughter handling with water shower spray iInhibits PSE (Pale, Soft, Exudative) broiler breast meat in a commercial plant. Biochemical and ultrastructural observations. Journal Food Biochemistry, 28, 269-277.

Mitchell, M.A. and Kettlewell, P.J. (1998), Physiological stress and welfare of broiler chickens in transit: solutions not problem! Poultry Science, 77, 1803-1814.

Oda, S.H.I.; Nepomuceno, A.L; Ledur, M.C.; Oliveira, M.C.N.; Marin, S.R.R.; Ida, E.I.; Shimokomaki, M. (2009), Quantitative differential expression of alpha and beta ryanodine receptor genes in PSE (Pale, Soft, Exudative) meat from two chicken lines: broiler and layer. Brazilian Archives Biology and Technology, in press.

Olivo, R., Soares, A.L, Ida, E. I., Shimokomaki, M. (2001), Dietary Vitamin E inhibits Poultry PSE and improves meat functional properties. Journal Food Biochemistry. 25, 271-283.

Olivo, R. and Shimokomaki, M. (2006), Carne PSE em Frangos. In: Atualidades em Ciência e Tecnologia de Carnes Shimokomaki et al. eds., São Paulo: Varela, p. 95-104.

Soares, A.L.; Lara, J.A.F.; Ida, E.I.; Guarnieri, P.D.; Olivo, R.; Shimokomaki, M. (2002), Variation in the colour of Brazilian broiler breast fillet. Proceedings of $48^{\text {th }}$ International Congress of Meat Science and Technology, Roma, 48, 540-541.

Warriss, P.D.; Pagazaurtundua, A.; Brown, S.N. (2005), Relationship between maximum daily temperature and mortality of broilers chickens during transport and lairage. British Poultry Science,46, 647-6

Received: February 02, 2009; Revised: Juny 10, 2009 Accepted: February 12, 2010. 